\title{
Coupling of mantle-upwelling and shearing -Mesozoic dyke-swarms in Da-Hinggan Mountains, Northeast China
}

\author{
1. Department of Geology, Peking University, Beijing 100871, China \\ 2. China University of Geosciences, 29 Xueyuan Road, Beijing 100083, China \\ 3. Nei Mongol Bureau of Geology and Mineral Resources, Hohhot 010020, China
}

The morphological and petrologico-geochemical features, and the time-space evolution history of Mesozoic dyke-swarms in Da Hinggan Mts. are studied to explore the polytopism and polytrope of the driving forces for deformation of the continental lithosphere. It is found that two dynamic mechanisms were coupled in the deformation of the upper lithosphere when upwelling and intrusion of the mantle-derived magma occurred.

\section{Introduction}

In the early 1990s, 16 unsolved problems were put forward in the "National Program for Research in Continental Dynamics" in the United States (Xiao, 1997), intending to establish a theory of continental dynamics, which might be used to remedy the limitation of the plate-tectonics theory when used for the continental geology. One of these problems is the interaction of the continents with the plate movement system, which is vital for understanding how the driving force for deformation of the continental lithosphere should be both multivariant and polygenic. Continent-ocean transition belts should be the best places for exploring this problem, and the Da-Hinggan Mts. in northeastern China is right on such a transition belt between the Asian continent and the Pacific. Uplifting of the Da-Hinggan Mts. occured mainly in the Late Jurassic to Early Cretaceous, when the EastAsian continental margin was just in its shear movement stage. Geomechanically, the Da-Hinggan Mts. is attributed to the third uplift belt of the Neocathaysian System, which is intimately related to the levogyric shearing of the Asian continent relative to the Pacific. Recent researches on the Mesozoic crust-mantle source magmatism in the Da-Hinggan Mts. (Zhao, et al., 1989) which, combined with the current thinning of the lithosphere there, leads to the idea of correlation of the DaHinggan Mts. uplift with an upwelling of the mantle or asthenosphere (Shao, et al., 1995). Then the problem of how the mantle-upwelling and shearing could exist concurrently in the process of Da-Hinggan Mts. uplift concerns with the polytope and polytropism of the driving forces for deformation of the continental lithosphere. And the unique geographic position of the $\mathrm{Da}$ Hinggan Mts. also makes its uplift involve interactions between the movements respectively from depth in the inner continent and from plate tectonics in the continental margin. This article will address this problem through the formation of Mesozoic dyke-swarms in the Da-Hinggan Mts.
A dyke-swarm is a group of hundreds of dykes of the same age arranged in a certain pattern. Basic dyke-swarms are most common, which are an important evidence of the tensional fracture of the crust from depth to the surface as well as a indication of the deep-level deformation of the crust in a large-scale extensional structure. For instance, the dyke-swarms in Deccan Plateau of India is thought to be representative of a continental rifting (Bhattacharji, et al., 1996). Dyke-swarms can not only provide information about the composition of deep materials, but also keep tracks of movements and deformation of the crust before the emplacement. They are, therefore, rare for exploring the coupled actions of mantle-upwelling and shearing.

\section{Kinetic characteristics reflected by the dyke-swarms}

The diabase dyke-swarms discussed here are distributed concentratedly around Fulingou and Jilinba, Linxi district in the southern section of the Da-Hinggan Mts., in an area of $80 \mathrm{~km}^{2}$ (Figure 1). There are two types of dyke-swarms, monomeric and compound. The monomeric ones are usually $0.5-1$ metre wide, whereas the compound ones consist of successive dykes without invaded rocks between them. The latter may sometimes be up to hundred metres

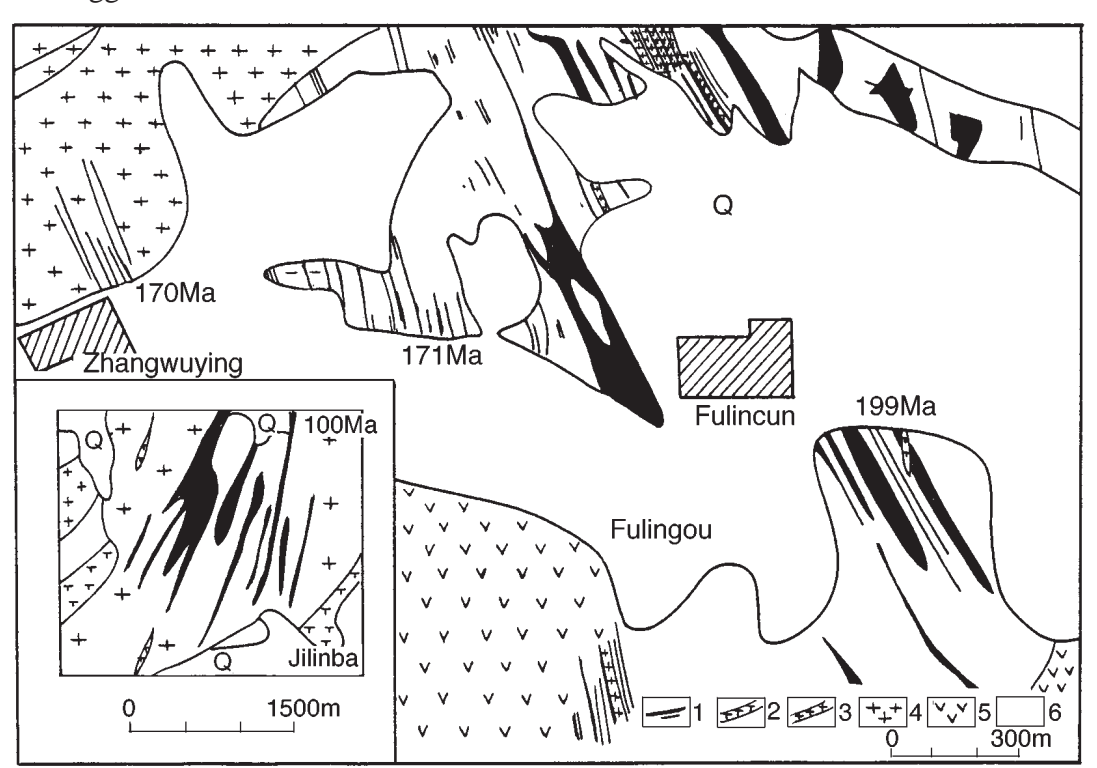

Figure 1 Geological sketch of the Fulingou dyke-swarms (modified by Yue Yongjun). 1-diabase dyke, 2-intermediate-basic vein, 3-granite vein 4-granite intrusive, 5-Lower Permian Dashizhai Fm. basalt, 6-Lower Permian Qingfeng-shan Fm. slate. 
Table 1 Comparison of morphological features of the Mesozoic dyke-swarms in different stages.

\begin{tabular}{|c|c|c|c|}
\hline & $\begin{array}{l}\text { Early Jurassic dyke- } \\
\text { swarms (199 Ma) }\end{array}$ & $\begin{array}{l}\text { Middle Jurassic dyke- } \\
\text { swarms (170 Ma) }\end{array}$ & $\begin{array}{l}\text { Early Cretaceous dyke- } \\
\text { swarms (100 Ma) }\end{array}$ \\
\hline Lithology & mainly diabase & diabase, diabase -prophyrite & mainly diabase -prophyrite \\
\hline Occurrence & $350^{\circ} / \mathrm{NE} \angle 60^{\circ}-80^{\circ}$ & $350^{\circ} / \mathrm{NE} \angle 70^{\circ}-80^{\circ}$ & $20^{\circ} / \mathrm{SE} \angle 70^{\circ}-88^{\circ}$ \\
\hline Form & $\begin{array}{l}\text { irregular partly, abrupt } \\
\text { contraction-expansion, } \\
\text { branched ends, saw-tooth- } \\
\text { like sides of compound } \\
\text { dyke-swarms, typical } \\
\text { features of tensile veins }\end{array}$ & $\begin{array}{l}\text { even and slender mostly, with } \\
\text { branch faults and drag folds, lateral } \\
\text { en echelon arrangement of some } \\
\text { veins, typical features of shearing- } \\
\text { tensile veins, compound } \\
\text { dyke-swarms common }\end{array}$ & $\begin{array}{l}\text { intermittent, relatively large size, } \\
\text { monomeric mostly, asymmetric } \\
\text { saw-tooth like sides of some veins, } \\
\text { obvious alteration-metasomatism } \\
\text { on edges, features of compresso- } \\
\text { shear plus tensile compound }\end{array}$ \\
\hline Invaded rocks & Lower Permian slate & $\begin{array}{l}\text { Lower Permian slate, basalt, } \\
\text { granite(169 Ma, Yue, Y.) }\end{array}$ & miarolitic granite \\
\hline Extension & & $7 \%$ & $20 \%$ \\
\hline
\end{tabular}

wide and hundreds metres long (the longest reaching $2 \mathrm{~km}$ ), quite spectacular a view. J. S. Lee in his book "The Geology of China" described the Mesozoic dyke swarms in Linxi district (Lee, 1939). Age estimations by K-Ar dilution method show that those distributed around Fulincun are of Early Jurassic (199.6 $\pm 6.9 \mathrm{Ma})$, those in Zhangwuying, Middle Jurassic $(170.4 \pm 5.2 \mathrm{Ma})$, and those in Jilinba, Early Cretaceous ( $100.6 \pm 2.7 \mathrm{Ma})$. Comparison of the morphological features of the three groups of dyke-swarms of different stages may help in discussion of the crustal movement in this area from $100 \mathrm{Ma}$ to $200 \mathrm{Ma}$ (Table 1 ).

It follows from the evolution of the dyke-swarms through the three stages that:

1. From $200 \mathrm{Ma}$ to $100 \mathrm{Ma}$, the upper crust in this area experienced a levogyric shear movement, which is clearly shown by the Early Jurassic diabase intrusion in the NW $330^{\circ}$-trending extensional fractures, Middle Jurassic intrusion in the NW $350^{\circ}$-trending shear-extensional fractures, and the induced structures. After a time interval in the Late Jurassic, a large-scale diabase intrusion occurred in the compresso-shear fractures caused by upwelling, and underwent obvious alteration-metasomatism with the surrounding miarolitic granite.

2. The compound dyke-swarms developed in the Early and Middle Jurassic extend continuously from their central line toward both sides, like those formed in oceanic ridges but with much less extension rate. The dykes formed in different stages not only have different colours and compactnesses of rocks, by which distinct monomers can be identified, but also have different chemical compositions of rocks. Take the South Fulincun dyke-swarm as an exam- ple. The data in Table 2 are taken from five samples representative of dykes formed in three intrusions. It can be seen that the symmetric parts have similar chemical compositions, and that from both sides toward center $\mathrm{SiO}_{2}, \mathrm{MgO}$, and $\mathrm{Na}_{2} \mathrm{O}$ increase gradually, but $\mathrm{FeO}^{*}$ and $\mathrm{K}_{2} \mathrm{O}$ decrease. Such a structure can not be explained with chilling or crystal fractionation in a single intrusion because the supposed chilling borders seem too thick and neither cryptomerous nor glassy texture is found in samples G1 and G5. Besides, if the supposed chilling borders really exist, their composition should close to that of the original magma, but actually $\mathrm{Mg}^{\prime}$ increases successively from both sides toward center. Thus such a symmetric structure may well be considered as a compound dyke formed by a pulsating magma provision, in which the intervals are not long enough for the adjacent dykes to reach their solid phase and hence without chilling borders formed.

Another feature relating to the pulsating dyke-swarm activity is the upward vertical force exsiting in the dyke intrusion, exampled by the fir-tree-like diabase dyke seen in the Zhangwuying section, where diabase forms downward branch veins toward both sides along conjugate joints. It follows that the concerned area has experienced an upward vertical action from depth alongside the regional levogyric shearing during the period of $100 \mathrm{Ma}$ to $200 \mathrm{Ma}$. The upward action was related with thermal upwelling in this period, which will be discussed through the petrologico-geochemical characteristics of the dyke-swarms. However, dyke-swarms are not the sole basis to determine a thermal upwelling but only a link of it.

Table 2 Composition of the south Fulincun compound dyke-swarm

\begin{tabular}{|c|c|c|c|c|c|c|c|c|c|}
\hline & Width & Grain & Colour & $\mathrm{SiO}_{2}$ & $\mathrm{MgO}$ & $\mathrm{Fe}_{2} \mathrm{O}_{3}$ & $\mathrm{~K}_{2} \mathrm{O}$ & $\mathrm{Na}_{2} \mathrm{O}$ & $\mathrm{Mg}^{\prime}$ \\
\hline G1 & $35 \mathrm{~cm}$ & fine & gray-black & 46.56 & 6.93 & 10.73 & 0.92 & 2.03 & 0.54 \\
\hline G2 & $60 \mathrm{~cm}$ & mid & black-green & 48.23 & 7.39 & 10.61 & 0.51 & 2.10 & 0.55 \\
\hline G3 & $30 \mathrm{~cm}$ & gross & gray-green & 49.08 & 7.47 & 10.26 & 0.37 & 2.49 & 0.57 \\
\hline G4 & $60 \mathrm{~cm}$ & mid & black-green & 48.29 & 7.24 & 10.90 & 0.41 & 2.37 & 0.54 \\
\hline G5 & $30 \mathrm{~cm}$ & fine & gray-green & 45.87 & 6.49 & 10.61 & 0.57 & 2.24 & 0.52 \\
\hline
\end{tabular}


Table 3 Main chemical constituents of the dyke-swarms

\begin{tabular}{|c|c|c|c|c|c|c|c|c|c|c|}
\hline & \multirow[t]{2}{*}{ No } & \multirow[t]{2}{*}{$\mathrm{SiO}_{2}$} & \multirow[t]{2}{*}{$\mathrm{MgO}$} & \multirow[t]{2}{*}{$\mathrm{K}_{2} \mathrm{O}$} & \multirow[t]{2}{*}{$\mathrm{Na}_{2} \mathrm{O}$} & \multirow[t]{2}{*}{$\mathrm{Mg}^{\prime}$} & \multirow[t]{2}{*}{$\mathrm{FeO}^{*}$} & $\mathrm{FeO}$ & \multirow{2}{*}{$\frac{\mathrm{La}_{\mathrm{N}}}{\mathrm{Yb}_{\mathrm{N}}}$} & \multirow{2}{*}{$\frac{{ }^{87} \mathrm{Sr}}{{ }^{86} \mathrm{Sr}}$} \\
\hline & & & & & & & & $\mathrm{Fe}_{2} \mathrm{O}_{3}$ & & \\
\hline $\mathrm{J} 1$ & 7 & 47.69 & 7.41 & 0.61 & 2.55 & 0.56 & 10.45 & 3.47 & 1.69 & 0.7036 \\
\hline $\mathrm{J} 2$ & 4 & 49.13 & 6.61 & 0.62 & 2.60 & 0.56 & 9.13 & 3.41 & 3.05 & 0.7044 \\
\hline K1 & 2 & 47.73 & 8.63 & 0.90 & 1.97 & 0.66 & 8.12 & 2.75 & 1.37 & 0.7048 \\
\hline
\end{tabular}

Notes: No indicates the number of samples for bulk rock analysis. $\mathrm{Mg}^{\prime}=\mathrm{Mg} /(\mathrm{Mg}+\mathrm{Fe})$.

\section{Petrologico-geochemical characteristics of the dyke-swarms}

The diabase rocks in this area are characterized by their low $\mathrm{FeO} * / \mathrm{MgO}$ and $\mathrm{K}_{2} \mathrm{O}(<0.8 \%)$ and high $\mathrm{Na}_{2} \mathrm{O}(>2 \%)$, being a suite of plutonic rocks with relatively high alkaline (Table 3 ) and falling mostly into gabbro-norite (tholeiite) in the $\mathrm{R}_{1}-\mathrm{R}_{2}$ petrochemical diagram with very few into olivine-gabbro or gabbro (Figure 2). A silicoalkali diagram analysis shows that they are subalkalic system rocks, displaying tholeiitic tendency in the AMF diagram. According to CIPW standard mineral classification, the Jurassic diabases are quartz-tholeiite system rocks, and the Cretaceous diabases are olivine-tholeiite system rocks. A $\mathrm{F}_{1}-\mathrm{F}_{2}$ diagram $\mathrm{SiO}_{2}-\mathrm{Al}_{2} \mathrm{O}_{3}$ diagram of the clinopyroxene, and a $\mathrm{Zr} / \mathrm{Y}-\mathrm{Zr}$ diagram (Figure 3 ) are used to distinguish the tectonic background in which the rocks form. The diagrams show that the diabases in this area are all intraplate tholeiites (WPT).

Geochemical characteristics of the REE, trace elements, and isotopes all reveal that the materials of the dyke-swarms in this area were originated from the upper mantle. The total REE-s are rela-

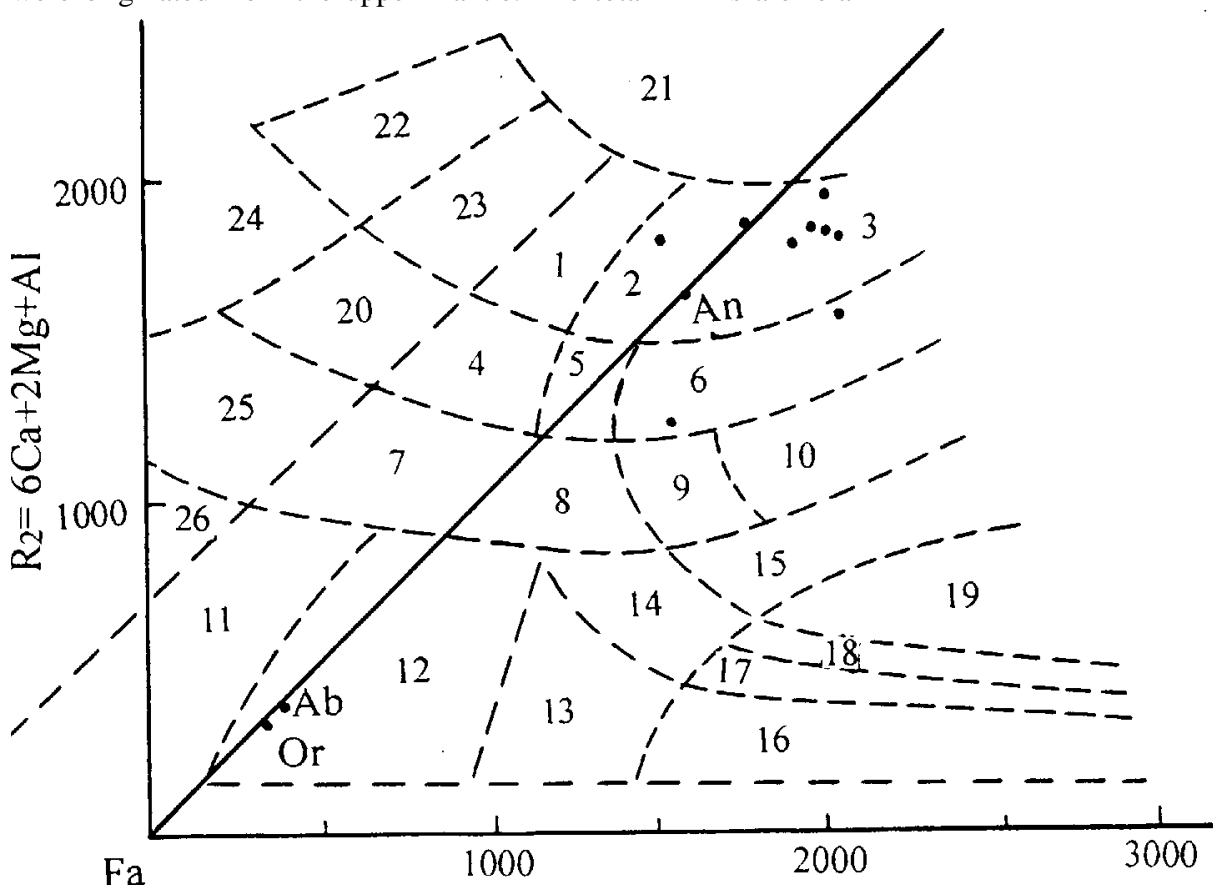

$$
\mathrm{R}_{1}=4 \mathrm{Si}-11(\mathrm{Na}+\mathrm{K})-2(\mathrm{Ti}+\mathrm{Fe})
$$

Figure $2 R_{1-} R_{2}$ petrochemical diagrams of the diabases (De La Roche et al., 1980) 1-alkalic diabase (alkalic basalt) 2-olivine-gabbro (olivine-basalt) 3-gabbro-norite (tholeiite) 4-syenogabbro (trachy basalt) 5-monzogabbro (latite basalt) 6-gabbro (basalt) tively low $\left(\right.$ REE $\left.42.5-89.6 \times 10^{-6}\right)$, their distribution patterns are slightly sloping downward or even, without europium depletion except for the Early Cretaceous diabase. Among the trace elements, the mantlephile high-field-strength inertial element $\mathrm{Nb}$ is relatively rich $\left(37.6-48.4 \times 10^{-6}\right), \mathrm{Ti}\left(7080-11460 \times 10^{-6}\right)$ and $\mathrm{Hf}(2.05-4.19 \times$ $10^{-6}$ ) have relatively high abundance, but the magmatophile elements $\mathrm{Zr}$ and Ta are relatively depleted, all indicating an upper-mantle origin of the magma. Sinks of incompatible elements can be seen in the spiderdiagram of the trace elements, where Th ranges $0.586-1.96 \times 10^{-6}$, U $0.267-0.705 \times 10^{-6}$, and $\mathrm{Th} / \mathrm{U} 1.95-3.46$, whereas the usual values of the three parameters are $4 \times 10^{-6}, 0.5 \times 10^{-6}$ and 4 respectively ( Liu et al., 1984). Depletion of Th is just a typical feature of the basalt developed in the beginning of a continentalrift $(\mathrm{Li}, 1992)$. Proportion of $\mathrm{Mg}^{\prime}$ is as high as $0.68-0.75$ in the original magma (Frey, et al., 1978), while $\mathrm{Mg}^{\prime}$ of the diabase in this area reaches $0.56-0.66$. In addition, the value of $\mathrm{La} / \mathrm{Nb}$ can also indicate the degree of hybridism with the crust (Wilson, 1989): the value of $\mathrm{La} / \mathrm{Nb}<1$ is for ocean island basalt, continental alkalic basalt, and kimberlite; whereas $0.5-7$ for continental flood basalt. The value of $\mathrm{La} / \mathrm{Nb}=1.14-1.44$ for the diabase of this area indicates a relatively low degree of hybridism with the crust, which in turn reveals an extensional setting of the lithosphere, in which the magma was able to rise rather rapidly. Besides, the ${ }^{87} \mathrm{Sr} /{ }^{86} \mathrm{Sr}$ value of $0.7036-0.7048$ for the diabase in this area (Table 3), when compared with the original value of less than 0.7037 for the mantlesource basalt magma unassimilated with the crust, also shows that the Early Jurassic magma in this area was not hybridized.

Comparison of the diabases of different stages may reveal the evolution of the dykeswarms and their relations with the surrounding environment during the period $200 \mathrm{Ma}$ to $100 \mathrm{Ma}$. It can be seen from Table 3 that there exists a tendency of increase in $\mathrm{SiO}_{2}, \mathrm{La}_{\mathrm{N}}$ $/ \mathrm{Yb}_{\mathrm{N}}$, incompatible elements, and ${ }^{87} \mathrm{Sr} /{ }^{86} \mathrm{Sr}$ as well as decrease in $\mathrm{MgO}$ and $\mathrm{FeO}^{*}$ from Early to Middle Jurassic, which demonstrates that both the Early and Middle Jurassic dykeswarms came from the same magma chamber, but there is a crystal-fractionation connection between them. However, the Early Cretaceous dyke-swarms not only have a rather large time gap (about $40 \mathrm{Ma}$ ) from the Early and Middle Jurassic dyke-swarms, but also differ from them in the geochemical features of elements with lower $\mathrm{SiO}_{2}$, higher $\mathrm{MgO}$ and $\mathrm{Mg}^{1}$, lower (REE and $\mathrm{La}_{\mathrm{N}} / \mathrm{Yb}_{\mathrm{N}}$, and eventype REE distribution patterns. There should be, therefore, no crystal -fractionation connection between the Early Cretaceous and Jurassic diabases. The former may represent 


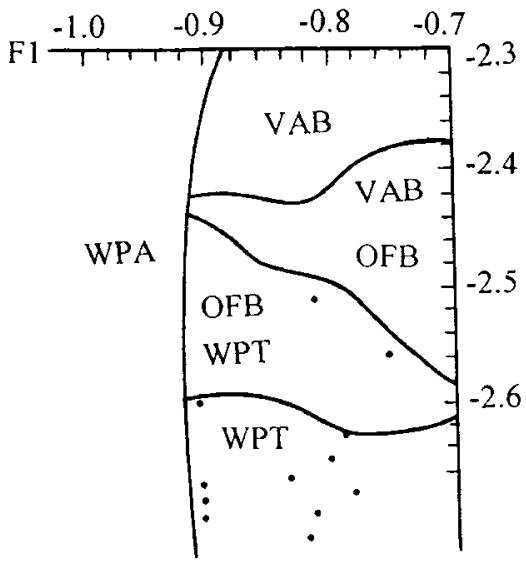

F2

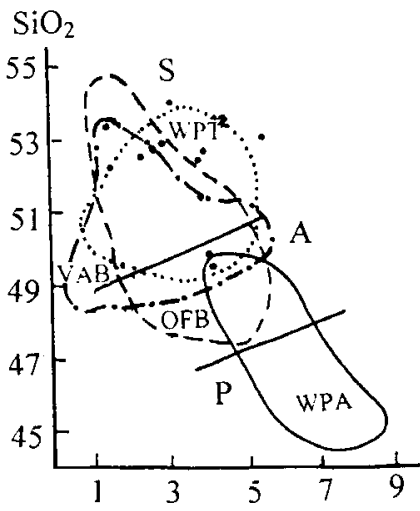

$\mathrm{Al}_{2} \mathrm{O}_{3}$

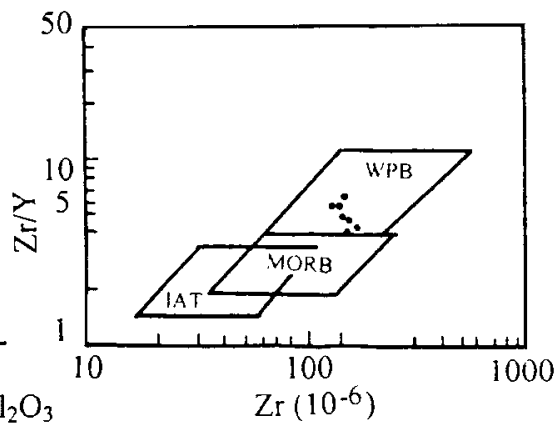

Figure 3 Tectonic background distinguishment of diabase formation. Left: F1-F2 Diagram of clinopyroxene (Nisbet, J. A. et al., 1977); Middle: $\mathrm{SiO}_{2}-\mathrm{Al}_{2} \mathrm{O}_{3}$ diagram of clinopyroxene (Qiu, J., 1991); Right: $\mathrm{Zr}$-Zr/Y diagram (Pearce, J.A. et al., 1979).

VAB-volcanic-arc basalt, OFB-ocean-floor basalt, WPT-intraplate tholeiite, WPA-intraplate alkalic basalt, WPB-intraplate basal, MORB-mid-ocean ridge basalt, IAT-island-arc basalt.

another magma activity likely originated from the relatively depleted mantle after the Jurassic differentiation, and the joining of a magma with deeper origin and lower melting degree is not excluded.

\section{Temperature-pressure conditions and tectonic background for formation of the dyke-swarms}

As an evidence of extension of the upper lithosphere, the dykeswarms should contain important information about the tectonic background under which the magma underwent its upwelling and crystallization. Measurement of the contents of clinopyroxene and pyroxene-phanerocryst in the diabase may help to determine the temperature and pressure at which the dyke-swarms crystallized (Table 4). It can be seen from the table that the magma chamber in the Middle Jurassic is the deepest, being located in the upper mantle or lower crust; the magma chamber rose obviously in the Middle Jurassic; and the depth of the magma chamber increased again in the Early Cretaceous. The Early Cretaceous dyke-swarms are mainly diabase-prophyrite, showing that the magma rose and chilled rather rapidly inspite of the deepened magma chamber. That is related to the regional structural evolution history of the area: it experienced large-scale strong volcanic eruptions in the Late Jurassic, leading to a suite of volcanic rocks named Meiletu Group (consisting of olivine-basalt, trachyandesite, and acid crystal-vitric ignimbrite, with an $\mathrm{Rb}-\mathrm{Sr}$ isochron dating of $121 \mathrm{Ma}$ and a ${ }^{87} \mathrm{Sr} /{ }^{86} \mathrm{Sr}$ value of 0.7047 for the volcanic rocks) before the Early Cretaceous dykeswarm intrusion. Long duration and repeated volcanic eruptions caused well-developed fractures in the mid-upper crust, which

Table 4 Temperature and pressure during the decrystallization of dyke-swarms

\begin{tabular}{|c|c|c|c|}
\hline $\begin{array}{r}\text { Temperature } \\
\left({ }^{\circ} \mathrm{C}\right)\end{array}$ & $\begin{array}{l}\text { Pressure } \\
\qquad(\mathrm{GPa})\end{array}$ & $\begin{array}{l}\text { Depth of } \\
\text { Formation }(\mathrm{km})\end{array}$ & $\begin{array}{l}\text { Deferred depth of } \\
\text { magma chamber }(\mathrm{km})\end{array}$ \\
\hline $\mathrm{J}_{1} \quad 1128.0-1170.6$ & $0.86-1.24$ & $28.2-40.8$ & $\geq 40.8$ \\
\hline $\mathrm{J}_{2} \quad 1040.3-1118.7$ & $0.30-0.77$ & $10.0-25.0$ & $24.0-25.0$ \\
\hline $\mathrm{K}_{1} \quad 1084.9-1151.5$ & $0.47-1.07$ & $15.0-23.2$ & 35.0 \\
\hline
\end{tabular}

Note: Calculated with equations by Qiu, J., 1987. increased the permeability and made the magma able to rise and condense rapidly.

Before the Early Jurassic dyke-swarm intrusion, there appeared several mantle-source rock enclaves wrapped by diorite and ultramafic rocks, whose age is $240-210 \mathrm{Ma}$, mainly of Late Triassic. They are thought to be products of deep actions during the tectonic transition stage from the Asian domain into the Pacific domain (Shao et al., 1997). From the viewpoint of the entire Mesozoic thermal evolution history, the intrusion of the dyke-swarms should be one of the links in the thermal upwelling process. Coupling of the deep source vertical thermal upwelling with the lateral regional shearing, namely the multivariant and polygenic driving forces, determined the integral forms and features of the dyke-swarms. The former is related to the material sources of the dykes, and the latter, to the spatial distribution of materials in the mid-upper crust. Both of them have their own dynamic origins, interact with each other, and affect concurrently the existing geological characters. When problems of intraplate structures are concerned, the deep activities should be considered as important and essential factors.

\section{Acknowledgements}

This work is supported by Natural Science Foundation of China (49672156).

\section{References}

Bhattacharji Chatterjee, N.,Wampler,J.M.,1996,Indian intraplate and continental margin rifting, lithospheric extension and mantle upwelling in Deccan flood basalt volcanism near the K/T boundary: evidence from mafic dike swarms, Journal of Geology, Vol.104, No.4, pp. 379-398.

Frey, F.A., et al., 1987, Integrated models of basalt petrogenesis: A Study of quartz tholeiites to olivine melilitites from South Eastern Australia utilizing geochemical and experimental petrological data., J. Petro., Vol.19, pp.463-513.

Lee, J. S., 1939, The geology of China, London: Thomas Murby Co.

Li, C., 1992, Trace element petrology of igneous rocks, Publishing House of China University of Geosciences. (in Chinese)

Liu, Y., Cao, L., Li, Z., 1984, Element geochemistry, Beijing : Science Press. (in Chinese)

Shao, J., Zang, S., Mu, B., Li,X., Wang, B., 1995, Extension of orogenic belts and upwelling of asthenosphere: the example of Hinggan-Mongolian orogenic belt, Chinese Science Bulletin, Vol.40, pp.50-56. 
Shao, J., Mu, B., He, G., Zhang, L., 1997, Plutonism in transformation from Peleo-Asian Domain to Paleo-Pacific Domain, Science in China (Series D), Vol.27, No.5, pp.390-394.

Wilson, M., 1989, Igneous petrogenesis, London: Unwin Hyman Ltd.

Xiao, Q., 1997, Some significant scientific frontiers in studies of continental dynamic, Shaanxi Geology-Mineral Resources Information, No.2, Vol.22, pp.1-12. (in Chinese)

Zhao, G., Yang, G., Wang, Z., Fu, J., \& Yang, Y., 1989, Mesozoic volcanic rocks in central and southern Da Hinggan Ling Range, Beijing Press of Science and Technology. (in Chinese)
Feng Gai, working with the Chinese Center of Training for Quality Assurance, received her Master of Science degree from China University of Geosciences (Beijing). Her major field is petrology.

Luqiao Zhang, a research fellow of geology, graduated from Peking University in 1964 and used to be the chief engineer of the Geological Institute of Inner Mongolia. His main research interest is regional geology.
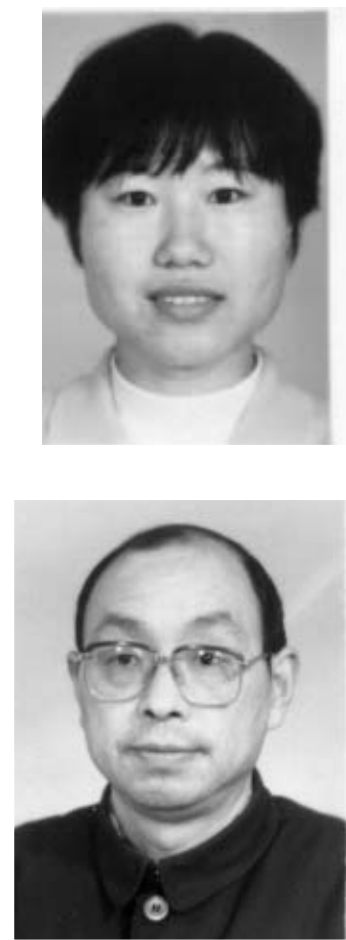

Ji'an Shao, a professor of Geology in Peking University, graduated from the same university in 1965. She is now a visiting research fellow at both the Research Center for Mineral and Resource Exploration, Academia Sinica and the Laboratory of Lithosphere Tectonic Evolution in Institute of Geology, Academia Sinica. Her research interest is concentrated on orogeny and continental margin evolution.

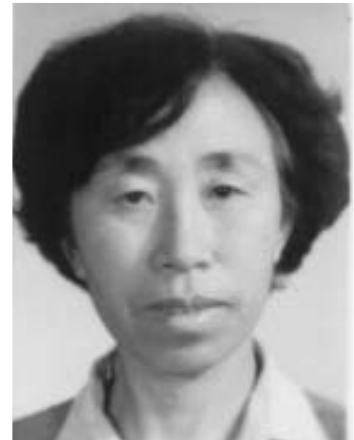

\section{$31^{\text {ST }}$ INTERNATIONAL GEOLOGICAL CONGRESS}

Rio de Janeiro - Brazil August 6 -17 - 2000

- The First Circular was issued on April 301998.

- Return Preliminary Questionnaire contained in the Circular before November1st, 1998.

- Additional copies of the First Circular may be requested by e-mail: 31igc@31igc.org.

- For details contact:

Secretariat Bureau, 31st IGC::

Av. Pasteur, 404-Casa Brazil 2000 - Urca

Rio de Janeiro - RJ - Brazil - Cep 22.290-240

Tel: 55212955847 -

Fax: 55212958094

E-mail: 31igc@31igc.org -

http://www.31igc.org

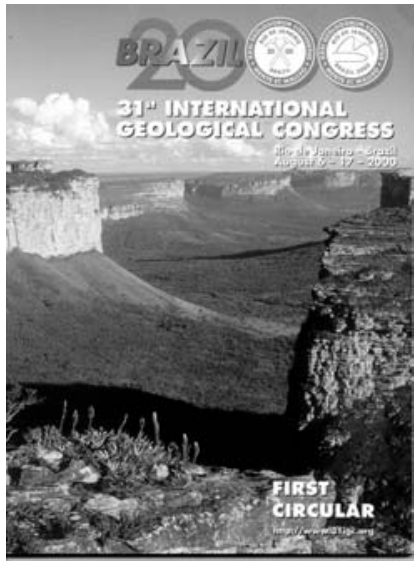

